\section{FIGHTING FOR LIFE}

Seven NASA planetary missions are competing against each other for extensions.

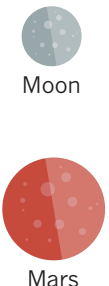

Lunar Reconnaissance Orbiter Launched: 2009

Annual operating cost*: $\$ 8.1$ million

Mars Odyssey

Launched: 2001

Cost: $\$ 12.3$ million

Opportunity rover

Launched: 2003

Cost: $\$ 13.2$ million

Mars Express

Launched: 2003, by the

European Space Agency.

Cost (to NASA): $\$ 3$ million

Mars Reconnaissance Orbiter

Launched: 2005

Cost: $\$ 29.5$ million

Curiosity rover

Launched: 2011

Cost: $\$ 59.4$ million

\section{Cassini}

Launched: 1997

Cost: $\$ 65.7$ million

Saturn

* Latest year available

- near its south pole.

Smaller missions are also angling for a piece of the division's pie. Those running the Mars Odyssey spacecraft, which was launched in 2001 and is the longest-lived Martian spacecraft ever, are moving the craft into a different orbit. That would allow it to look at the red planet from dusk and dawn angles that have not been tried since the 1970s. The Odyssey team is also trying to play up the fact that the orbiter is an essential communications tool: it is in a favourable orbit for relaying information from rovers on the Martian surface to Earth. The newer Mars Reconnaissance Orbiter also acts as a relay, but that mission has suffered several glitches in recent years.

For now, all the planetary missions under review are running as planned until the end of this
"You always have to keep in mind that this could be the end of the mission." fiscal year. Mem-

bers of the review panel should be named shortly, and are due to meet in May and report their recommendations to Green, for his decision in June.

Stephen Mackwell, head of the Lunar and Planetary Institute in Houston, Texas, thinks that NASA officials will find a way to keep most of the missions going, especially if the project teams can show a way to take the science in a new direction. "Business as usual is not a sustainable approach," he says.

\title{
Software patents await legal fate
}

\section{Supreme Court ruling could affect medical-diagnostics firms.}

\section{BY HEIDI LEDFORD}

$\mathrm{F}$ or the first time in more than 30 years, the US Supreme Court is tackling one of the most vexing questions in patent law: can software be patented? Its decision could affect the future of personalized medicine.

On 31 March, the court will hear arguments in Alice Corporation v. CLS Bank International, a lawsuit over four patents on software intended to reduce risk in financial transactions. The case is the latest example of Supreme Court efforts to rein in the US Patent and Trademark Office, which is notoriously permissive in granting commercial protection to inventions. Two years ago, the court struck down a class of patent often used to protect medical diagnostic tests. Last year, it ended a 30-year tradition of issuing patents on naturally occurring genes.

With the latest case, the court has the potential to restrict software patents, with repercussions not only for the technology industry, but also, yet again, for medical-diagnostics companies, says Jonathan Masur, deputy dean of the University of Chicago Law School in Illinois, who specializes in intellectual property. "It's enormously important," he says.

Software patents are controversial. Critics charge that they tend to be vague and cover obvious inventions, and that they hinder innovation. They are magnets for 'patent trolls' businesses that collect broad patents mainly to force others to pay licensing fees. Some critics also argue that computer programs are simply the expression of mathematical formulae, and thus can be considered abstract ideas, which, along with laws of nature, are not patentable.

Yet in 1981, the Supreme Court conceded that some software could be patented, and since then the number of software patents has soared.

The Alice case began in 2007, when CLS Bank International, based in New York, sued Alice Corporation of Melbourne, Australia, charging that four of Alice's patents were invalid. Alice countersued CLS Bank for infringing the same patents. But CLS Bank could be in a good position, if the Supreme Court's interest in limiting patentability in recent years is any indication (see 'Valid concerns'). Observers are hoping that the court will use the case to develop concrete criteria to determine which software patents are valid. "The problem with the law to date is that it's very subjective," says Robert Sachs, a partner

\section{VALID CONCERNS}

The US Supreme Court (pictured) is clamping down on the kinds of inventions that can be patented.

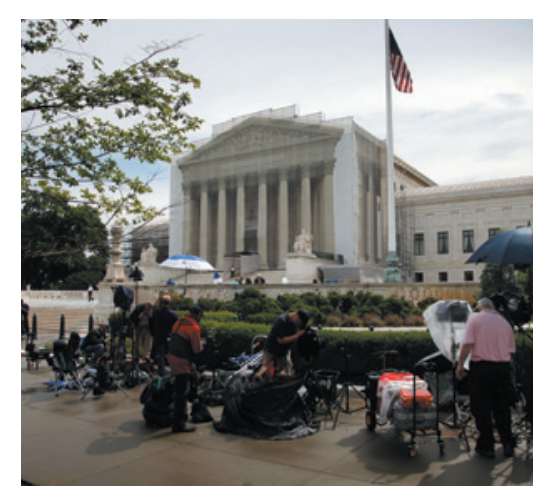

\section{NOVEMBER 1972 Gottschalk v.}

Benson. Ruled that computer programs cannot be patented if they merely perform mathematical calculations.

\section{MARCH 1981 Diamond v. Diehr.} Ruled that a device controlled by a computer program was patentable reopening the door to software patents.

\section{APRIL 2007 KSR International}

v. Teleflex. Threw out a patent on an adjustable accelerator-pedal system for being too obvious.

JUNE 2010 Bilski v. Kappos. Struck down a business-methods patent, saying it was based on an abstract idea.

MARCH 2012 Mayo Collaborative Services v. Prometheus Laboratories. Said two medical-diagnostics patents were based on laws of nature, and invalid.

JUNE 2013 Association for Molecular Pathology v. Myriad Genetics. Ruled that natural genes cannot be patented.

2014 Alice Corporation v. CLS Bank International. Arguments heard on software patents. 
at the law firm Fenwick and West in San Francisco, California. "Every judge gets to decide: "Is this the kind of thing that I think a patent claim ought to cover?"”

To bolster its arguments, CLS Bank is citing a 2012 case, Mayo Collaborative Services v. Prometheus Laboratories, that struck down two medical-diagnostics patents and sent tremors through the diagnostics industry. The patents covered the act of measuring metabolites to determine the proper dosage of certain drugs used to treat autoimmune diseases. The nine judges on the Supreme Court unanimously decided that the patents merely laid claim to a law of nature - the body's breakdown of the drugs - and were therefore invalid.

The Mayo ruling represented a fundamental change, says Brian Dorn, a patent attorney at the Barnes \& Thornburg law firm in Minneapolis, Minnesota, who counts diagnostics companies among his clients. "It's been hard to get around," he says. "We've been getting patent rejections based on that case." Some even blame the court's decision for a drop in US venture-capital investment in medical-diagnostics companies - from US\$395 million in 2011 to $\$ 278$ million in 2013, according to London-based consultancy firm PricewaterhouseCoopers.

Mayo is also setting a precedent for lower courts. Last October it was used, along with the 2013 Association for Molecular Pathology v. Myriad Genetics ruling that invalidated patents on genes (see Nature 498, 281-282; 2013), to throw out key patents on a prominent non-invasive prenatal test for Down's syndrome, held by the diagnostics company Sequenom of San Diego, California. The ruling, by a California district court, used a strict interpretation of Mayo, says Christopher Holman, a law professor at the University of Missouri-Kansas City Law School. "If that is how the courts are going to use that case, it's a very bad sign for industry," he says.

The Alice case could be a chance for the Supreme Court to clarify how Mayo should be interpreted, says Masur: rulings on abstract ideas (as is likely to arise from Alice) are often applied to arguments about patenting laws of nature (as in Mayo). If the Supreme Court invalidates many kinds of software patents, for example, diagnostics firms could be in for more trouble, he says.

The Supreme Court's tendency towards restricting patents is a concern for Gregory Graff, an agricultural economist who studies intellectual property at Colorado State University in Fort Collins. He argues that the US patent system should not be reformed through a series of radical court decisions. Instead, he would prefer to see legislation and patent-office procedures tweaked as fields of technology evolve. "You don't need the nuclear option of blowing a hole in what's deemed patentable," he says. .

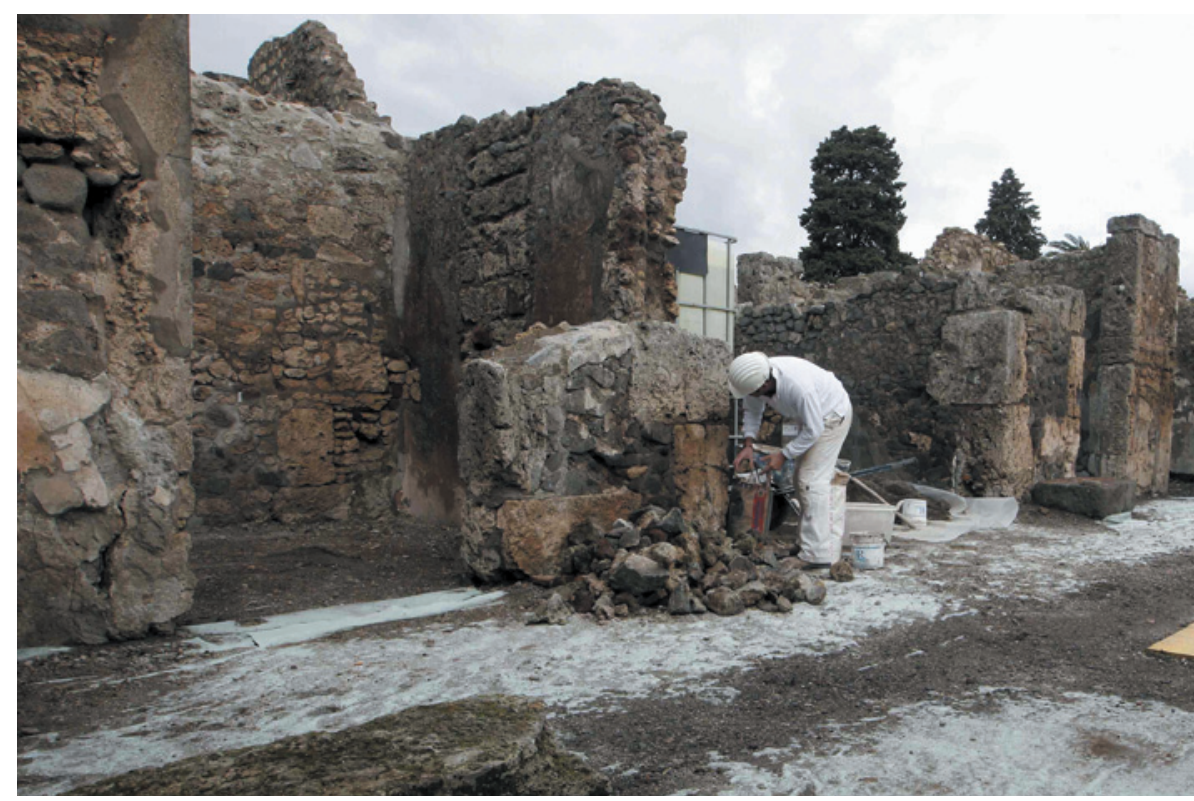

Conservation work under the Great Pompeii Project began at the site in 2013.

ARCHAEOLOGY

Sister city inspires
Pompeii rescue

\section{Archaeologists hope that funding and conservation boost can halt decay of ancient city.}

\section{BY DECLAN BUTLER}

A ncient Pompeii, which suffered three wall collapses this month, may look to its smaller sister city Herculaneum for tips to ensure its survival. Both cities, located on Italy's Neapolitan coast, were simultaneously destroyed and preserved by the eruption of Mount Vesuvius in AD 79, but the historic site of Herculaneum is faring much better, thanks to a sustainable conservation project.

Now an international research consortium is planning a similar pilot scheme for Pompeii. And researchers and officials are hoping that a $€ 105$-million (US\$145-million) European Union project to restore Pompeii will also draw on lessons from Herculaneum.

The rescue plan cannot come soon enough. "A lot of buildings are at risk [of collapse]," one anonymous observer close to the restoration efforts told Nature, adding that, as well as the repair effort, "they need a system to maintain the site so that it doesn't happen again".

Excavations of Pompeii, which, with Herculaneum, is a World Heritage Site of the United Nations Educational, Scientific and Cultural Organization, began in the mideighteenth century. But conservation took off only in the early twentieth century, by which time much of the city had been reduced to walls. However, decay at the 66-hectare site has accelerated since the 1960s as a result of haphazard funding and the disbanding of in-house maintenance crews.

This month's collapses are the latest in a series of incidents since the 1980s. Water is the site's biggest enemy: unexcavated embankments absorb rainfall and exert pressure on adjoining structures, and poor drainage allows surface water to accumulate. A lack of regular repair work means that rain also seeps into the walls.

Much of Pompeii's masonry consists of rubble stonework, which is highly vulnerable. Typically, this consists of two wall coverings assembled with roughly placed stones of volcanic tuff (opus incertum), together with a core of smaller stones set in a lime-mortar grout (opus caementicium).

Such constructions show excellent longevity if kept dry. But water infiltration has led to repeated wetting and drying, causing stones to chip and flake, and the mortar to decay and lose cohesion. In addition, many twentieth-century conservation interventions at Pompeii have since proved inappropriate and damaging.

The authorities are responding, however. 